\title{
GEOGRAPHICAL OVERVIEW OF WATER BALANCE OF SLOVENIA 1971-2000 BY MAIN RIVER BASINS
}

\section{GEOGRAFSKI PREGLED VODNE BILANCE SLOVENIJE 1971-2000 PO GLAVNIH POREĆJIH}

Peter Frantar

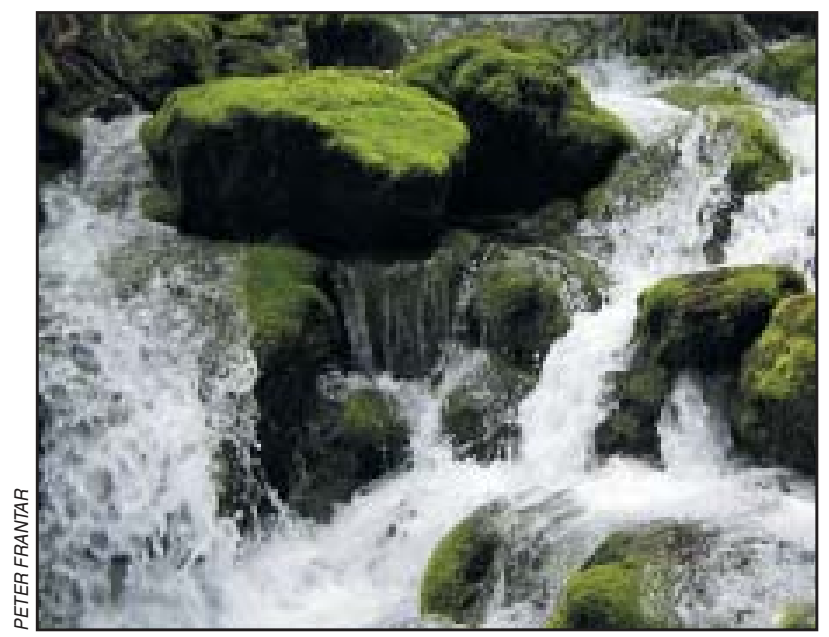

Surface runoff is only a part of water balance.

Površinski odtok je le del vodne bilance.

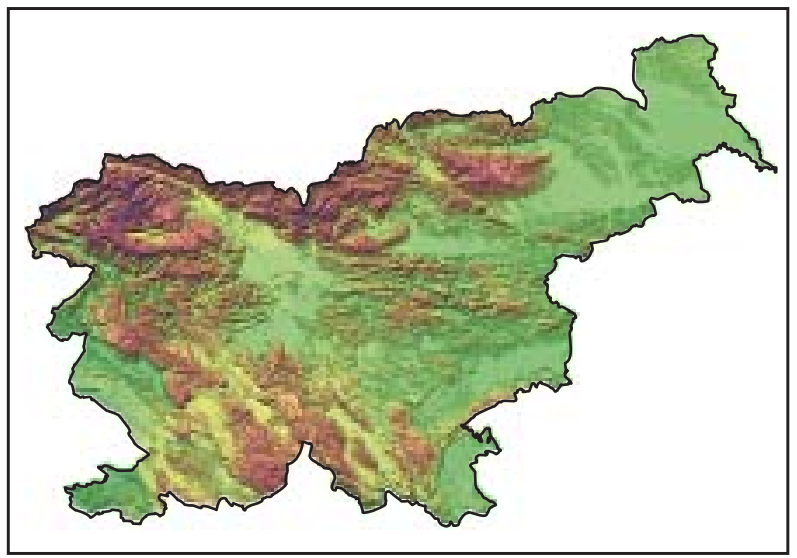




\title{
Geographical overview of water balance of Slovenia 1971-2000 by main river basins
}

\author{
UDC: 911.2:556.512(497.4)"1971/2000" \\ COBISS: 1.01
}

\begin{abstract}
This overview of the hydrogeographical characteristics of the Slovenian water balance 1971-2000 reviews three main water cycle elements: precipitation, evapotranspiration and runoff. Results show their spatial distribution and strong interdependency in by main river basins of Slovenia. Greatest amounts of water are in the Soča river basin and the smallest in the Slovenian part of the Mura river basin. Average yearly quantities of water in Slovenia for the period 1971-2000 are: precipitation $1579 \mathrm{~mm}$, evapotranspiration $717 \mathrm{~mm}$ and runoff $862 \mathrm{~mm}$. Compared with the water quantities data of 1961-1990 period, the precipitation is in same rank, the evapotranspiration increased and the runoff decreased. Despite being a »wet « country by world standards, available water resources in Slovenia are declining.
\end{abstract}

KEYWORDS: hydrogeography, water balance, precipitation, evapotranspiration, runoff, river basins, Slovenia

The article was submitted for publication on December 27, 2006.

\section{ADDRESS:}

Peter Frantar, B. Sc.

Environmental Agency of the Republic of Slovenia Vojkova cesta 1b, SI - 1000 Ljubljana, Slovenia

E-mail: peter.frantar@rzs-hm.si

\section{Contents}

1 Introduction $\quad 27$

2 Methodology of analysis of water balance elements 27

2.1 Precipitation 27

2.2 Evapotranspiration 28

2.3 Runoff 28

3 Water balance of Slovenia 28

3.1 Precipitation 28

$\begin{array}{ll}3.2 & \text { Evapotranspiration }\end{array}$

3.3 Runoff 32

4 Water balance in main river basins 34

$4.1 \quad$ Mura river basin $\quad 35$

$\begin{array}{lll}4.2 & \text { Drava river basin } & 35\end{array}$

$\begin{array}{ll}4.3 & \text { Sava river basin } \\ 4.45\end{array}$

4.4 Kolpa river basin $\quad 35$

4.5 Soča river basin 36

4.6 Adriatic sea watershed without
Soča river basin

5 Conclusion 36

6 References $\quad 37$ 


\section{Introduction}

Water on Earth is available in all three physical states: liquid, gaseous and solid. It may be found in all environments that are important for humans: air, sea and land. Water passes between all the physical states and the environments both in space and in time. It has the character of dynamic medium (WMO 1994; Jones 1997).

This article shows the characteristics of water cycle elements in the river basins of Slovenia. Water balance is the separation of the hydrological processes of the water cycle based on system analysis, both in space and time. The hydrological system is the sum of all elements, its interdependencies and characteristics, that are all part of the overall water cycle in the bounded area (Fürst 2006; Schöniger et al. 2003; Neff et al. 2004). It is a simple system that is very complicated to analyse (Davie 2004).

\section{Methodology of analysis of water balance elements}

The water balance equation evolved from the water cycle theory of water circulating between atmosphere and the earth's surface (Van Abs et al. 2000; Kolbezen et al. 1998; WMO 1997; Schöniger et al. 2003). The equation of the water balance is:

precipitation $=$ runoff $(\mathrm{Q})+$ evapotranspiration $(\mathrm{E})+$ storage changes $(\mathrm{dS})$.

Water balance is an open system (Hong et al. 2006) where the inputs and outputs of water are calculated. The main systems input in the World is precipitation and the main output is evapotranspiration (Ritter 2006). As we will reveal, this does not apply for Slovenia.

In the process of this water balance calculation for Slovenia, the water storage changes were not considered. We presumed that this element can be neglected due to longterm period (Kolbezen et al. 1998; Frantar et al. 2005; Berezovskaya et al. 2005). Thus storage changes are very important in yearly water balance calculations (Koczot et al. 2004; Sloto et al. 2005; Neff et al. 2005).

The equation used in our analysis is simplified and presumes equilibrium of precipitation, evapotranspiration and runoff:

precipitation $(\mathrm{P})=\operatorname{runoff}(\mathrm{Q})+$ evapotranspiration $(\mathrm{E})$.

The main goals of analysis are to confirm the results of the calculated raster layers for the precipitation and evapotranspiration (made from point source data layers) with the (direct) runoff measurements on water gauging stations; and to derive the raster layer of 1971-2000 runoff with the use of the two layers mentioned above. Water balance elements were compared and corrected with the use of the water balance error method. The use of (measured) runoff results confirmed the regularity of precipitation and evapotranspiration rasters. This enabled us to make the raster water balance analysis of Slovenia (Figures 1, 3, 5).

\subsection{Precipitation}

Precipitation is defined as atmospheric water condensating or sublimating from air, falling towards the surface and eventually falling on the ground surface (DIN 1996, cited after Schöniger et al. 2003). Precipitation is the most important climate element of hydrological system (Fürst 2006) because it is the sole input of the water cycle in natural conditions (Van Abs. et al. 2000). There are various forms of precipitation uniformly presented as a liquid water eqvivalent (Frantar et al. 2006a; Fürst 2006).

Precipitation measurements are recorded in many different locations of Earths surface.

A total of over 200 measurement sites were selected: 193 measurement sites were selected with more than 25 years of data, 8 with less with 29 sites located in Austria and Croatia. The foreign stations are important due to the high relief energy in border areas and due to the watersheds lying outside of the state of Slovenia (Frantar et al. 2006d).

Appropriate values of measurements are gained by transferring point locations into the space (Schöniger et al. 2003) and with the systematic error corrections (WMO 1994; Fürst 2006). Systematic errors are mostly the result of wind, wetting, evaporation, spills or snow problems during the measurement (WMO 1994). The raw precipitation data was corrected using the dynamic correction model (Forland et. al. 1996; Nespor et al. 1999) that considers precipitation type, intensity and wind speed on a daily basis 
for a single precipitation event (Frantar et al. 2006a). The average correction factors gained in this analysis are very similar to the factors in described in the analysis of water balance 1961-1990 (Kolbezen et al. 1998).

\subsection{Evapotranspiration}

Evapotranspiration is of great importance to the water balance. It is the process of the physical transformation of water with temperatures under the dew point from solid or liquid state into gaseous state (Schöniger et al. 2003). Evapotranspiration combines the evaporation from the earth's surface and the transpiration from plants (Allen 1998; WMO 1994; Schöniger et al. 2003; Fürst 2006).

Reference evapotranspiration for period 1971-2000 was calculated using modified Hargreas method (Allen 1998) for 37 meteorological stations.

Data for minimum and maximum air temperatures and geoposition of the stations was used.

The Hargreas method was pounded with daily linear regression coefficients according to the Penman-Montheith method (Allen 1998). The reference evapotranspiration holds for grass surfaces with enough water in the soil. Therefore our data was corrected with the land cover type factors of the Corine Land Cover database (Frantar et al. 2006d). Evapotranspiration is locally very variable according to the land cover type (Jones 1997).

\subsection{Runoff}

In the water balance equation, the runoff is seen as the most accurately measured element. Under ideal conditions, all the water from the watershed is drained through one single measuring profile of a water gauging station. Therefore, only the water gauging stations of proper quality may be used in analysis. Out of over 700 stations, the ones with the defined standard time and space characteristics were used. With this process of multiple comparisons of water balance elements, the hydrometrical units as a basis of water balance accounts were obtained. A hydrometrical unit is a surface delineated with the watershed divides, with known inputs on upstream water gauging stations and outflows on downstream water gauging station(s) (Frantar 2003). The results of water balance elements in one hydrometrical unit allow comparison between different hydrometrical units (Fürst 2006). With this process, the accuracy of the calculated precipitation and evapotranspiration values is confirmed or disproved by comparison with the measured runoff data. With enough conformity between the water balance elements, the raster data map of the mean annual runoff in mm can be made using climatological method with $\mathrm{Q}=\mathrm{P}-\mathrm{E}$ equation (Jones 1997).

\section{Water balance of Slovenia}

\subsection{Precipitation}

Mean annual precipitation in period 1971-2000 in Slovenia was $1579 \mathrm{~mm}$. The spatial distribution is also highly dependable upon the relief also in Slovenia (figure 1) (Schöniger et al. 2003; WMO 1994). Due to orographic effect the amount of precipitation increases from the sea towards inland, with maximums on the Dinaric-alpine mountain ridge. Highest mean precipitation (over $2600 \mathrm{~mm}$ ) is found on the southwestern side of Julian Alps and Mount Sneznik.

In other locations in the Julian Alps, the Karavanke region and in the high Dinaric plateau ridge, there is annually from 2000 to $2600 \mathrm{~mm}$ of precipitation. In the Kamnik-Savinja Alps, there is also a slightly smaller local maximum. On the coast, the amount of precipitation is from 1100 to $1200 \mathrm{~mm}$. Towards the northeast, behind the Dinaric plateau ridge, the precipitation decreases according to the distance from the sea and the altitude.

Higher amounts of precipitation are found only in Pohorje and Gorjanci region (up to $1800 \mathrm{~mm}$ ). 


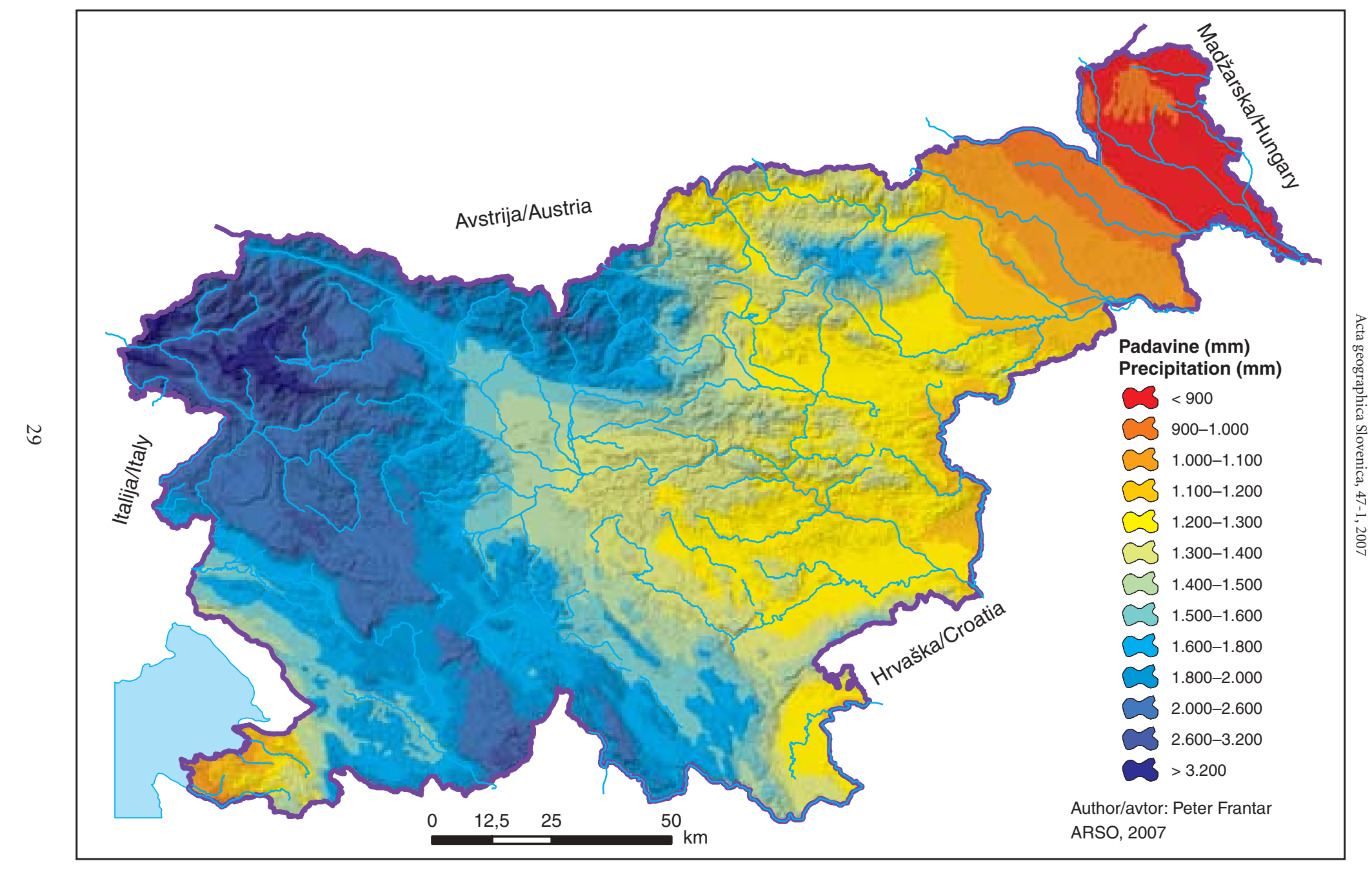




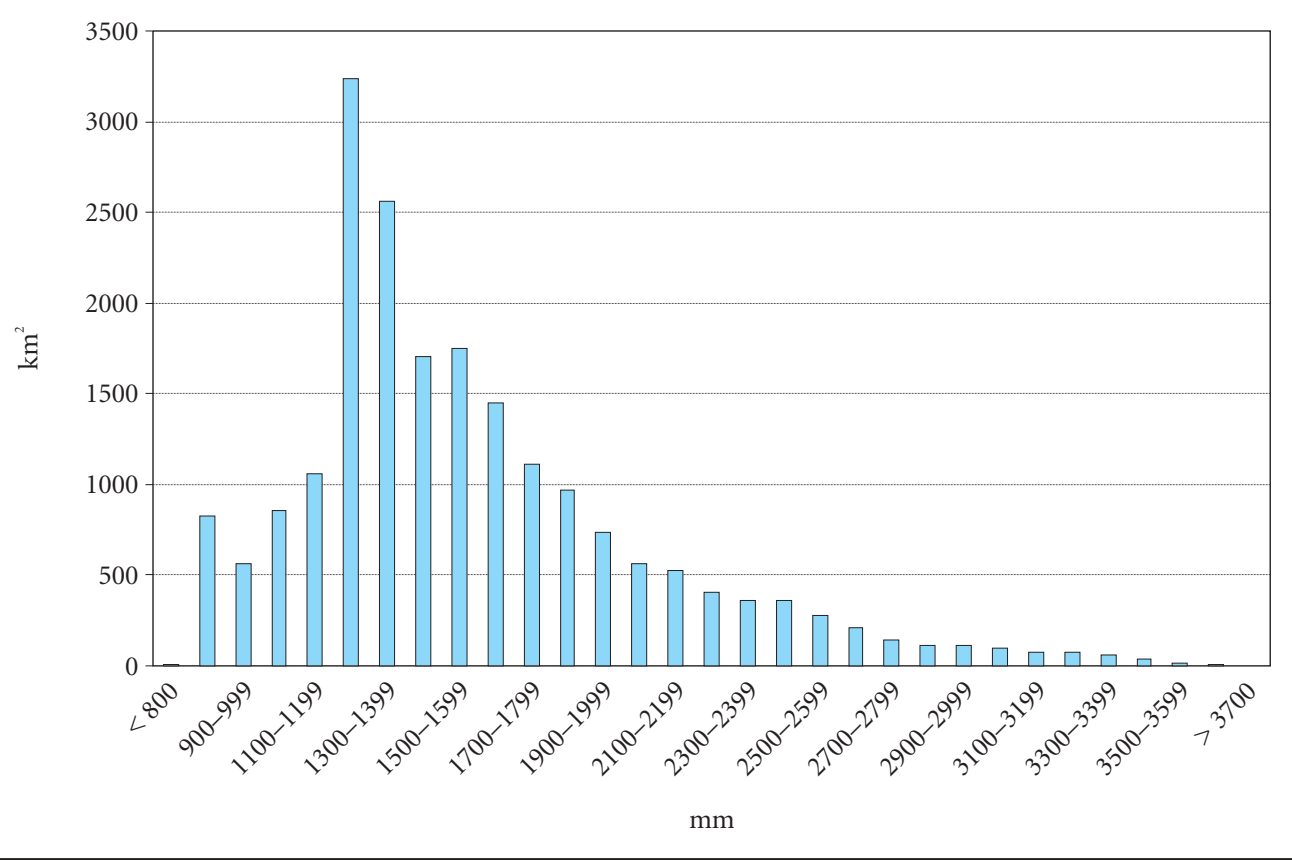

Figure 2: Area covered by precipitation classes in Slovenia.

In the Ljubljana basin, the precipitation amount decreases from north to south, from $1800 \mathrm{~mm}$ to $1300 \mathrm{~mm}$. Highest altitudes of the Posavsko mountains have up to $1400 \mathrm{~mm}$ of precipitation. From here to lower altitudes, and towards the north- and the south-east, the amount decreases to about $1200 \mathrm{~mm}$.

The Drava and the Ptuj lowlands receive between 1100 and $1200 \mathrm{~mm}$ precipitation yearly and precipitation decreases towards the northeast of state where the mean annual amounts average below $900 \mathrm{~mm}$.

\subsection{Evapotranspiration}

The evapotranspiration variability in space is the lowest of any water cycle element in Slovenia (figure 4). The total range of mean annual evapotranspiration in the period 1971-2000 is from 458 to $879 \mathrm{~mm}$ with a mean value of $717 \mathrm{~mm}$.

The spatial distribution is very crumbled and is highly dependant on the altitude and the type of land cover (figure 3). The highest evapotranspiration (rate) in Slovenia is over $850 \mathrm{~mm}$. In the east, this is found in the forested areas of Pomurje, in parts of the Krško-Brežice basin and in parts of the Bela Krajina region. In the west of state, high evapotranspiration is found on the coastal area of the Koper hills, in parts of the Vipava hills and in the western Karst areas.

The average values of Slovenia's evapotranspiration are spatially very crumbled due to the various types of relief and land cover.

Very low evapotranspiration, less than $600 \mathrm{~mm}$, is found in small patches of the mountains and hills. Slightly larger areas of very low evapotranspiration are only found on the southeast of Pohorje mountains, around the Bled area, on tops of the Julian Alps, in the Postojna-Pivka basin, in the Brkini region and in the areas of east Notranjska and west Dolenjska regions. In general evapotranspiration rates decrease from the south towards the northwest and the northeast. 


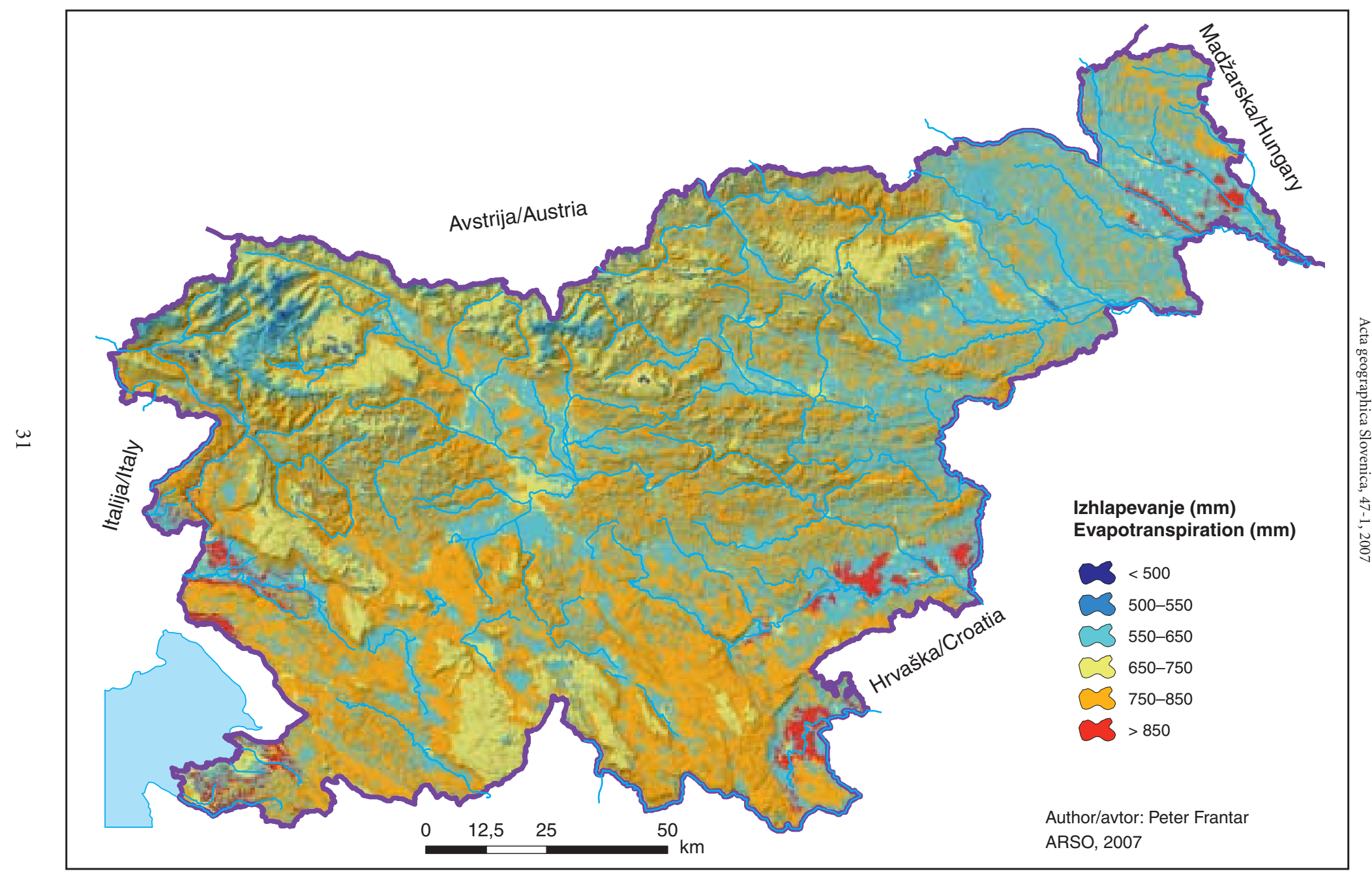




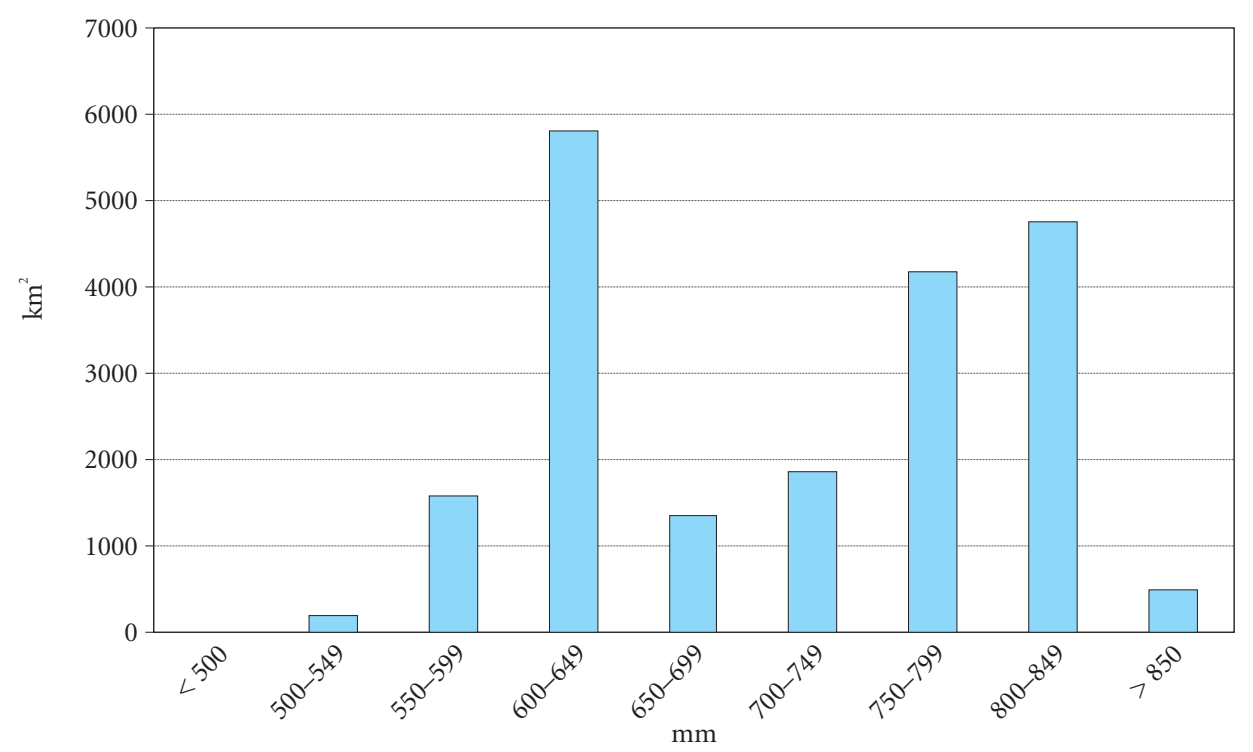

Figure 4: Area covered by evapotranspiration classes in Slovenia

\subsection{Runoff}

The physio-geographical diversity of Slovenia is greatly dependant on the runoff variability. Runoff amounts decrease from the Alpine-Dinaric mountains between the Julian Alps and Mount Sneznik towards the southwest and northeast. Mean annual runoff in the period 1971-2000 in Slovenia was $862 \mathrm{~mm}$. This amount is highly dependant on orography - in general higher altitudes have higher runoff as nearby lower altitudes.

The highest annual runoffs (over $2000 \mathrm{~mm}$ ) are in central parts of the Julian Alps, in the highest parts of Trnovski gozd and Mount Sneznik. These are the »wettest« regions of Slovenia with fast above and underground precipitation drainage.

Smaller areas of such high runoff are also found in the highest parts of the Karavanke Mountains and the Kamnik-Savinja Alps. Runoff here averages from 1500 to $2000 \mathrm{~mm}$ annually in the subalpine parts of Julian Alps and the western Dinaric plateaus from Banjšice to Mount Sneznik.

Areas with 1200 to $1500 \mathrm{~mm}$ runoff are found in western Slovenia in the hills around the Alps, in the hilly regions around the Škofjeloško and Idrijsko regions, in the northern part of the Goriška Brda region, in the western Dinaric plateaus fringes, in the Javorniki mountains and in the Gotenica region.

Averages of 900 to $1200 \mathrm{~mm}$ annual runoff are found in the area from the southern Goriška Brda region to Slavnik in the south, from the Dolina region to the eastern Kamnik-Savinja Alps, from the eastern Škofjeloško hill region to the Kočevska Mala mountain, Roga and Pohorje.

The runoff from 600 to $900 \mathrm{~mm}$ is found in the southwestern regions of Vipavska brda region, in Kras, in parts of Brkini region and in the eastern part of the Koper coastal region. The largest area with 900 to $1200 \mathrm{~mm}$ runoff is in central Slovenia and extends from the Suha Krajina region on the south over to the Ljubljana basin and on to the Pohorje and Kozjak regions. Low runoffs of between 300 and $600 \mathrm{~mm}$ are common in the Koper coastal region, in eastern Slovenia from the Bela krajina region to the Slovenske gorice area. The lowest annual runoffs of $300 \mathrm{~mm}$ annually are in the Pomurje region. In some places here, the evapotranspiration is greater than the precipitation. 


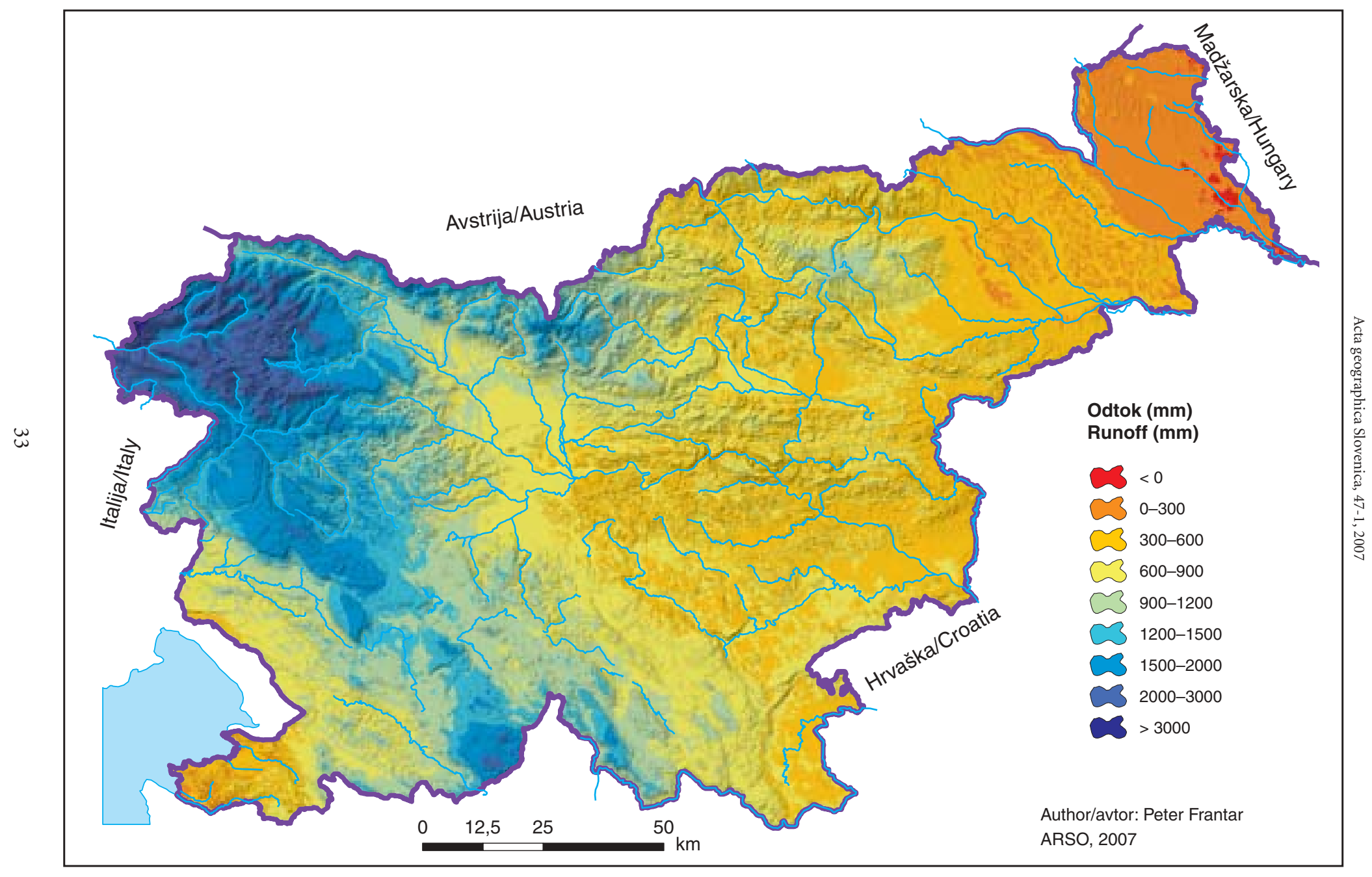




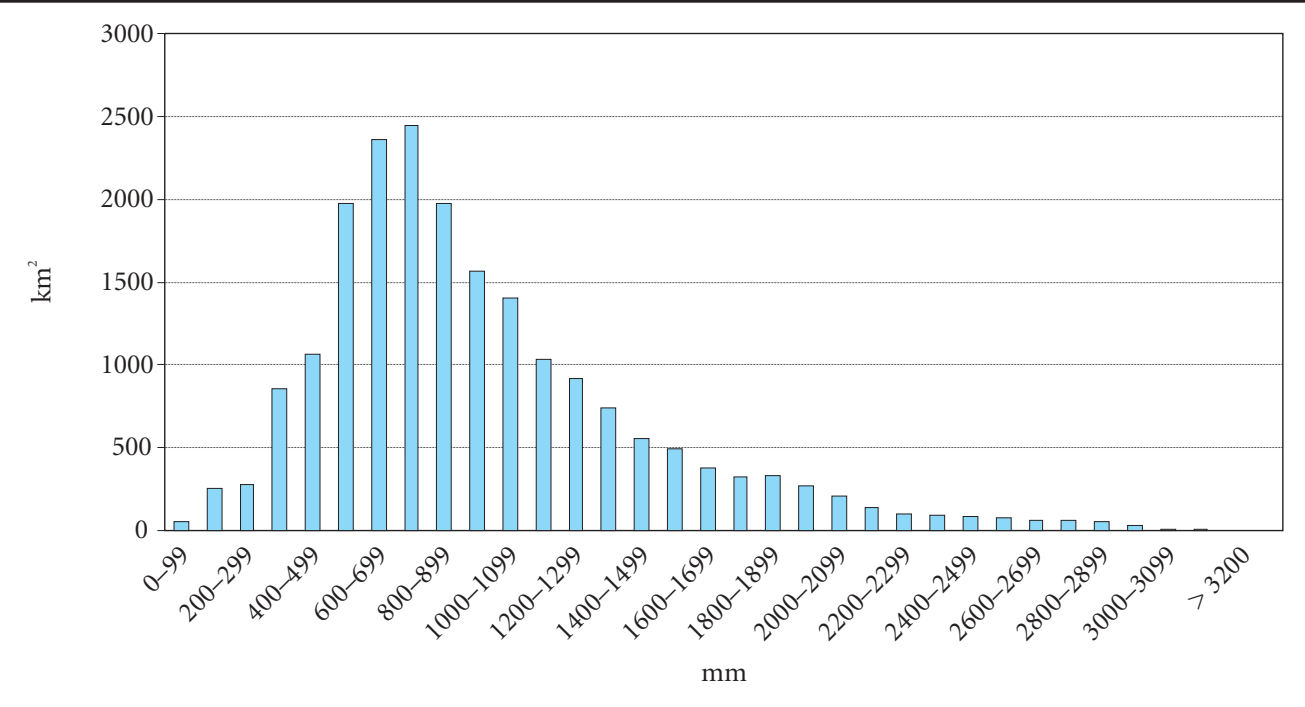

Figure 6: Area covered by runoff classes in Slovenia.

\section{Water balance in main river basins}

Water balance results show a great variability in the climatogeographical and hydrogeographical conditions in Slovenia's river basins. In this chapter, the precipitation, the evapotranspiration and the runoff in main river basins are presented.
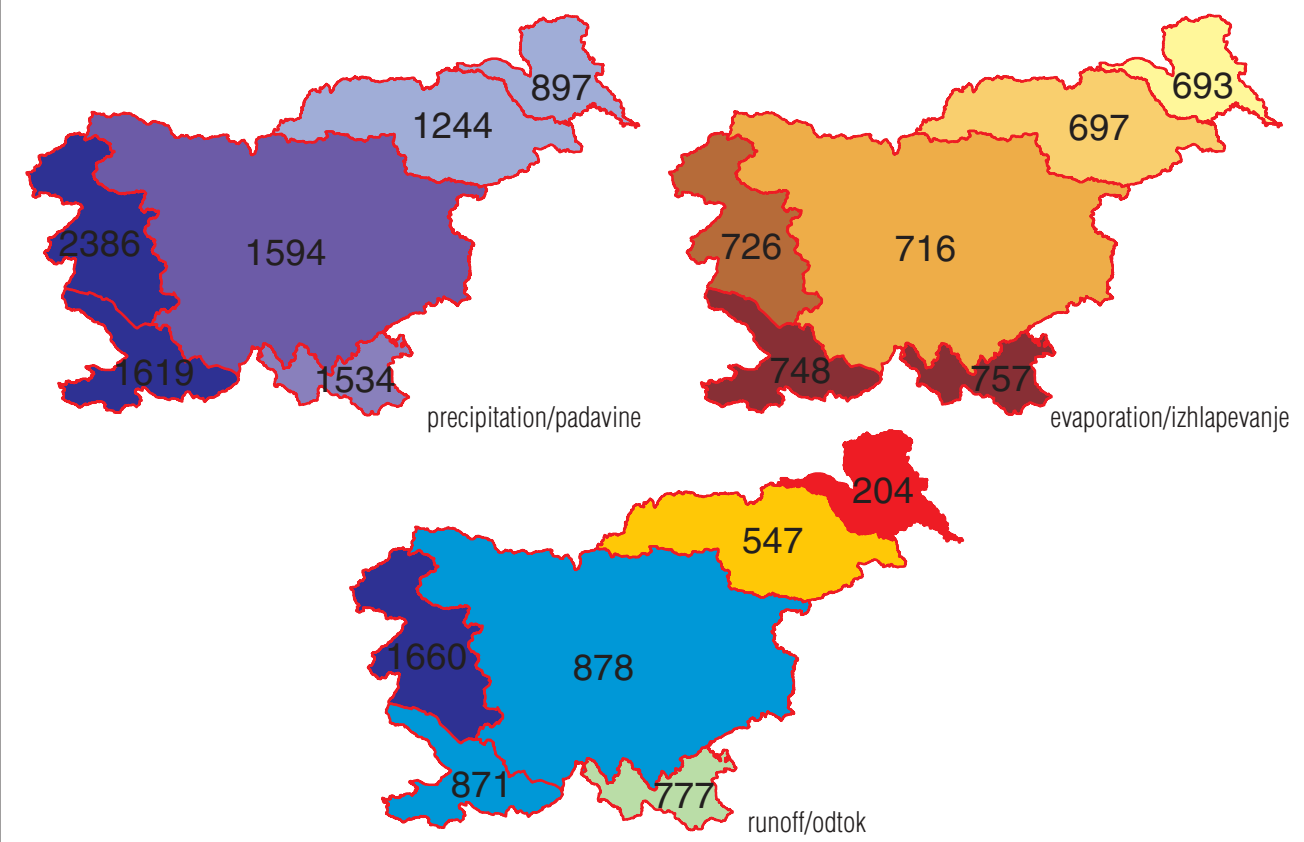

Figure 7: Water balance elements in $\mathrm{mm}$ in the main river basins. 


\subsection{Mura river basin (Pomurje)}

This is the region with the least water quantities in Slovenia. On average there is $897 \mathrm{~mm}$ of precipitation, $693 \mathrm{~mm}$ of evapotranspiration and $204 \mathrm{~mm}$ of runoff annually.

On the left side of Mura river, the precipitation amount is under $900 \mathrm{~mm}$ and in the most eastern part of the river, it is under $850 \mathrm{~mm}$. The highest precipitation of slightly more than $1000 \mathrm{~mm}$ is found on the Mura river's right side in the Slovenske gorice area. Evapotranspiration has a very low variation with a value of $693 \mathrm{~mm}$ on average; the highest evapotranspiration occurs in the forest areas. From these two water balance components, we can easily see the consequence: low runoff values. The runoff values here are the lowest in the state, decreasing from $300 \mathrm{~mm}$ on the right side of Mura river towards the east. In some places, the evapotranspiration is greater than the precipitation-runoff difference as the plants derive their water from shallow underground aquifers that gain water from transit streams (Mura river).

\subsection{Drava river basin (Podravje)}

The Slovenian part of river Drava drainage basin has more variety than the Mura river basin. The Drava river basin can be divided in three regions: the Slovenske gorice, the southern lowlands including the Drava valley and the mountainous northern part of the Pohorje and Karavanke Mountains.

On average, there is $1244 \mathrm{~mm}$ of precipitation, $697 \mathrm{~mm}$ of evapotranspiration and $547 \mathrm{~mm}$ of runoff, annually. In the entire region, the precipitation is over $1000 \mathrm{~mm}$ annually. The lowest values are found in the Slovenske gorice area (around 1000 in south and 1100 in north) and the lowland areas of Haloze and the summits of Pohorje (around $1200 \mathrm{~mm}$ ).

From here, the amount of precipitation increases towards the higher parts of the Pohorje and Karavanke Mountains to over $1600 \mathrm{~mm}$ annually. Evapotranspiration in the Podravje is the lowest with less than $650 \mathrm{~mm}$ annually, in the Slovenske gorice area, in the lowlands and in the highest parts in the Pohorje region and in the Meža springs area. For most of the area of the river basin, evapotranspiration rates average around $700 \mathrm{~mm}$ annually. The highest values of over $800 \mathrm{~mm}$ annually are found in Haloze. The runoff spatial distribution is similar. It is lowest in the east ( $300 \mathrm{~mm}$ annually) and the highest in mountain tops of Pohorje and Karavanke Mountains with over $1100 \mathrm{~mm}$ of runoff annually.

\subsection{Sava river basin (Posavje)}

The Posavje region has on average $1594 \mathrm{~mm}$ of precipitation, $716 \mathrm{~mm}$ of evapotranspiration and $878 \mathrm{~mm}$ of runoff annually. The spatial distribution of precipitation in Posavje ranges widely. In the most wettest parts of the Julian Alps, in the spring watershed area of the Sava Bohinjka river, there is over $3000 \mathrm{~mm}$ of precipitation on average per year. From here, precipitation amounts decrease rapidly towards the north and the east. Over $2500 \mathrm{~mm}$ of precipitation annually are found only in nearby places: in Vrata valley, on Pokljuka plateau and in parts of the Jelovica plateau.

Most of the Julian Alps' plateaus, the Karavanke Mountains, the Kamnik-Savinja Alps and parts of the subalpine mountains and the Javorniki mountrains have from 2000 to $2500 \mathrm{~mm}$ of precipitation annually. Towards the east, the central part of Posavje area gets »only« on average 1400 and $1800 \mathrm{~mm}$ annually, and most of the eastern part of the Sava river basin receives even less than $1400 \mathrm{~mm}$ precipitation annually. The lowest amount of annual precipitation is found in the Sotla river watershed (less than $1200 \mathrm{~mm}$ annually). The lowest evapotranspiration rates in Posavje area is found in two areas: in the high mountain Alps (with under $550 \mathrm{~mm}$ annually) and in the Sotla river watershed (with around $650 \mathrm{~mm}$ annually).

Evapotranspiration rates for most of Posavje area is between 650 and $850 \mathrm{~mm}$ annually, it is less in the north and more in south. In specific, local areas (the Krško-Brežice basin) there are evapotranspiration rates annually of over $850 \mathrm{~mm}$. Posavje's runoff distribution is similar to the precipitation distribution. The highest runoff of over $2500 \mathrm{~mm}$ occurs in the alpine and subalpine areas. Towards east, this amount decreases to 300 to $600 \mathrm{~mm}$ of annually.

\subsection{Kolpa river basin (Pokolpje)}

The Slovenian part of the Kolpa river basin has $1534 \mathrm{~mm}$ of precipitation, $757 \mathrm{~mm}$ of evapotranspiration and $777 \mathrm{~mm}$ of runoff annual average. The highest precipitation amounts are found on in the west, in 
parts of Mt. Snežnik and in the Kočevje region - over 2000 mm annually. The central Kolpa area has on average around $1700 \mathrm{~mm}$ and the eastern area, around $1300 \mathrm{~mm}$ of precipitation annually. Evapotranspiration in the Kolpa river basin is high, from $650 \mathrm{~mm}$ to over $850 \mathrm{~mm}$ annually. Runoff is the highest in the upper Kolpa watershed - over $1600 \mathrm{~mm}$. It decreases rapidly towards east - the lowest values are in central Bela krajina region with around $400 \mathrm{~mm}$ of annual runoff.

\subsection{Soča river basin}

Posočje is the wettest region in Slovenia. Average annual values are: precipitation $2386 \mathrm{~mm}$, evapotranspiration $726 \mathrm{~mm}$, runoff $1660 \mathrm{~mm}$. Precipitation amounts decrease from the north to the south of the region. The highest altitudes have over $3000 \mathrm{~mm}$ annually, with the summits of the Julian Alps receiving over $3500 \mathrm{~mm}$ annually.

The alpine valleys have less precipitation - between 2300 and $2700 \mathrm{~mm}$ annually - due to earlier precipitation that falls over southern mountain ridges. The southwestern ridge of the high Dinaric plateaus from Kambreško, Banjšice to Trnovski gozd region have around $2300 \mathrm{~mm}$ annually. The subapline mountains, behind the for-mentioned plateaus, and on Mount Nanos have less precipitation: 2000 to $2300 \mathrm{~mm}$ annually. Less than $2000 \mathrm{~mm}$ of precipitation occurs in the Goriška Brda area and in parts of the Vipava valley. The lowest precipitation of $1500 \mathrm{~mm}$ annually is found in the lower Vipava valley and in the Vipavska brda area. Evapotranspiration is the highest in the southern parts of this area with over $850 \mathrm{~mm}$ and decreases in amount towards the north according to altitude. In high Julian Alps, there is only $550 \mathrm{~mm}$ of annual evapotranspiration.

There are high differences in runoff. In the Kanin area, the runoff is over $3000 \mathrm{~mm}$ annually while most of the Alps have runoffs higher than $2000 \mathrm{~mm}$ annually (valleys excluded). Over $1500 \mathrm{~mm}$ annually of runoff occurs in the Dinaric plateaus and central regions. In the foothills and the hinterland of the Dinaric plateaus, runoff values decrease. In the Idrijca valley, there is $1100 \mathrm{~mm}$ of runoff annually and in the Vipavska brda area, the amount decreases to $650 \mathrm{~mm}$ of annual runoff.

\subsection{Adriatic sea watershed without the Soča river basin}

The smallest hydrographical part of Slovenia includes the (Notranjska) Reka river basin and its direct Adriatic sea tributaries. On average, there is $1619 \mathrm{~mm}$ of precipitation, $748 \mathrm{~mm}$ of evapotranspiration and $871 \mathrm{~mm}$ of runoff annually. Highest precipitation values are found in the Snežnik region, with over $2500 \mathrm{~mm}$. From here, it decreases towards west to $1100 \mathrm{~mm}$ annually in the coastal areas and $1500 \mathrm{~mm}$ annually in the Karst region.

Evapotranspiration is the highest in parts of the Koper coastal region and in the southwest Karst (over $850 \mathrm{~mm}$ annually). Towards the north and the east, the evapotranspiration decreases, with the lowest values in the Snežnik mountain area - under $700 \mathrm{~mm}$ annually. On the contrary, runoff is the highest in the east (Snežnik mountain area), with over $2000 \mathrm{~mm}$ annually and decreases towards west to the Koper coastal region where the runoff is from 200 to $400 \mathrm{~mm}$ annually.

\section{Conclusion}

Overall, Slovenia is a wet country from a world point of view. The World land masses have on average $750 \mathrm{~mm}$ of precipitation, $480 \mathrm{~mm}$ of evapotranspiration and $270 \mathrm{~mm}$ of runoff per year - as described by Global Water Balance (Global Water Balance, 2006; Fürst, 2006).

In Slovenia, these values are much higher. In the period 1971-2000, the average annual precipitation is $1579 \mathrm{~mm}$, evapotranspiration $717 \mathrm{~mm}$ and runoff $862 \mathrm{~mm}$.

In addition, the runoff coefficient of Slovenia at over 55\% compared to the average World runoff coefficient with 36\% (Schöniger et al. 2003, cited after Baumgartner et al. 1996) which also shows that Slovenia is wet country.

Direct comparison of water balance of Slovenia in the 1971-2000 period with the period 1961-90 (Kolbezen et al. 1998) reveals that in the period 1971-2000, the precipitation amount was almost the same, 
the evapotranspiration increased and the runoff decreased. For the period 1971-2000, evapotranspiration increased by $11 \%$ and runoff values decreased by $6 \%$.

Table 1: Water balance of Slovenia in 1961-1990 and 1971-2000 in mm (Kolbezen et al. 1998).

\begin{tabular}{lcc}
\hline & $1961-1990$ & $1971-2000$ \\
\hline precipitation & 1567 & 1579 \\
evapotranspiration & 650 & 717 \\
calculated runoff $(Q=P-E)$ & 917 & 862 \\
runoff coefficient & $58,5 \%$ & $54,5 \%$ \\
\hline
\end{tabular}

Climate changes do also affect the water amounts. Better data to determine the effects of climate on water quantities would be yearly and decade water balance analyses for longer period. Most of the temperature and the hydrologic-storm climate change indicators (Houghton et al. 2001) reveal climate changes have occurred in Slovenia after the year 1990 (Nadbath 1999; Gabrovec 1998; Frantar 2004). From any viewpoint, the water resources are becoming more precious.

\section{References}

Allen, R. G., Perreira, L. S., Reas, D., Smith, M. 1998: Crop evapotranspiration - Guidelines for computing crop water requirements - FAO Irrigation and drainage paper. Technical Report. Rome, Food and Agriculture organization of United Nations. Rome.

Berezovskaya, S., Yang, D., Hinzman, L. 2005: Long-term annual water balance analysis of the Lena River. Global and Planetary Change 48, (1-3), 96-111, doi:10.1016/j.gloplacha.2004.12.006.

Davie, T., 2004: Fundamentals of Hydrology, Routledge Fundamentals of Physical Geography. Routledge. London.

Dolinar, M. 2006: Raster padavin 1971-2000. Resolucija 100×100 m. Agencija RS za okolje. Ljubljana.

Forland, E. J., Allerup, P., Dahltröm, B., Elomaa, E., Jonsson, T., Madsen, H., Perälä, J., Rissanen, P., Vedin, H., Vejen, F. 1996: Manual for Operational Correction of Nordic Precipitation Data. Norwegian Meteorological Institute. Oslo.

Frantar, P. 2003: Vrednotenje ustreznosti mreže vodomernih postaj na površinskih vodotokih v Sloveniji. Geografski vestnik 75-1. Ljubljana.

Frantar, P. 2004: Analiza temperaturnega režima in pojava ledu na Bohinjskem jezeru. Ujma, 17/18. Ljubljana.

Frantar, P. 2005: Vodna bilanca. Hidrološki letopis Slovenije 2002. Agencija Republike Slovenije za okolje. Ljubljana.

Frantar, P., Dolinar, M. 2005: Pregled elementov vodne bilance za območje Savinje v obdobju 1971-2000. Mišičev vodarski dan 2005. Maribor.

Frantar, P., Bat, M., Dolinar, M., Kurnik, B. 2006a: Water balance of Slovenia 1971-2000. Balwois 2006 Conference. Ohrid.

Frantar, P., Dolinar, M., Kurnik, B. 2006b: GIS Based Water Balance of Slovenia. $6^{\text {th }}$ Annual Meeting of the European Meteorological Society. Ljubljana. Internet: http://www.cosis.net/abstracts/EGU06/05689/ EGU06-J-05689.pdf?PHPSESSID=353d25199d45d80a959ef412085251e5 (30/5/2006)

Frantar, P., Dolinar, M., Kurnik, B. 2006c: GIS Based Water Balance of Slovenia. Geophysical Research Abstracts 8. European Geosciences Union 2006.

Frantar P., Dolinar, M., Kurnik, B., Jerovšek, J., Ovsenik Jeglič, T., Bartalanič, R., Hrvatin, M. 2006d: Poročilo o rezultatih projekta Vodna bilanca Slovenije 1971-2000. Interno poročilo. Agencija RS za okolje. Ljubljana.

Fürst, J. 2006: Gewässerkunde und Hydrometrie Vorlesung mit ÜbungenM LVA 816.100. Institut für Wasserwirtschaft, Hydrologie und konstruktiven Wasserbau. Universität für Bodenkultur. Wien.

Gabrovec, M. 1998: Triglavski ledenik med letoma 1986 in 1998. Geografski zbornik 37. Ljubljana.

Global water balance. Internet: http://www.research.umbc.edu/ tokay/summerstudent2001_figures.pdf $(15 / 11 / 2006)$ 
Hong, N., Al-Khatib, W., Maganga, B., McLoughlin, A., Coe, B. 2006: System theory. Internet: www.ed.psu. edu/insys/ESD/systems/theory/SYSTHEO2.htm (15.12.2006)

Houghton, J. T., Ding, Y., Griggs, D. J., Noguer, M., van der Linden, P. J., Dai, X., Maskell, K., Johnson, C. A. 2001: Climate Change 2001: The Scientific Basis. Cambridge University Press. Cambridge. Internet: http://www.grida.no/climate/ipcc_tar (21.2.2003).

Jones, J.A. A. 1997: Global Hydrology. Addison Wesley Longman Limited. Essex.

Koczot, K. M., Jeton, A. E., McGurk, B. J., Dettinger, M. D. 2004: Precipitation-Runoff Processes in the Feather River Basin, Northeastern California, with Prospects for Streamflow Predictability, Water Years 1971-1997. Scientific Investigations Report 2004-5202. United States Geological Survey. Sacramento.

Kolbezen, M., Pristov, J. 1998: Površinski vodotoki in vodna bilanca Slovenije. Ministrstvo za okolje in prostor, Hidrometeorološki zavod Republike Slovenije. Ljubljana.

Kurnik, B. 2006: Raster evapotranspiracije 1971-2000. Resolucija $100 \times 100$ m. Agencija RS za okolje. Ljubljana.

Nadbath, M. 1999: Triglavski ledenik in spremembe podnebja. Ujma 13. Ljubljana.

Neff, B.P., Nicholas, J. R. 2004: Uncertainty in the Great Lakes Water Balance. Scientific Investigations Report 2004-5100. United States Geological Survey. Sacramento.

Nespor, V, Sevruk, B. 1999: Estimation of wind-enduced error of rainfall gauge measurements using a numerical simulation. Journal of Atmospheric and Oceanic Technology 16. Boston.

Schöniger, M., Dietrich, J. 2003: Hydrologie, Grundvorlesung mit Übungen. Hydroskript. TU Braunschweig. Braunschweig. Internet: www.hydroskript.de (15.12.2006).

Sloto, R. A., Buxton, D. E., 2005: Water Budgets for Selected Watersheds in the Delaware River Basin, Eastern Pennsylvania and Western New Jersey. Scientific Investigations Report 2005-5113. United States Geological Survey. Sacramento.

Van Abs, D. J., Stanuikynas, T. J. 2000: Water Budget in the Raritan River Basin. A Technical Report for the Raritan Basin Watershed Management Project New Jersey Water Supply Authority. Internet: http://www.raritanbasin.org/Reports/WaterBudgetReport.pdf (23.1.2006).

WMO, World Meteorological Organisation 1994: Guide to hydrological practicies, Data acquisition and processing, analysis, forecasting and other applications. WMO 168. World Meteorological Organisation. Geneva.

WMO, World Meteorological Organisation 1997: Water resources assessment, Handbook for review of national capabilities. United nations educational scientific and cultural organisation. World Meteorological Organisation. Geneva. 



\section{Geografski pregled vodne bilance Slovenije 1971-2000 po glavnih porečjih}

UDK: 911.2:556.512(497.4)"1971/2000"

COBISS: 1.01

IZVLEČEK: Pregled hidrogeografskih značilnosti vodne bilance Slovenije v obdobju 1971-2000 zajema tri glavne elemente vodnega kroga: padavine, izhlapevanje in odtok. Rezultati kažejo na njihovo prostorsko razporeditev in na močno soodvisnost vseh treh glavnih elementov vodne bilance po glavnih porečjih. Najbolj namočeno je Posočje, najmanj pa Pomurje. Povprečno je v Sloveniji v obdobju 1971-1990 padlo $1579 \mathrm{~mm}$ padavin, izhlapelo $717 \mathrm{~mm}$ in odteklo $862 \mathrm{~mm}$. V primerjavi z obdobjem 1961-1990 je količina padavin ostala približno enaka, povečalo se je izhlapevanje, odtok pa se je zmanjšal. Količina razpoložljivih vodnih virov v Sloveniji se zmanjšuje.

KLJUČNE BESEDE: hidrogeografija, vodna bilanca, padavine, izhlapevanje, odtok, porečja, Slovenija

Uredništvo je prejelo prispevek 27. decembra 2006.

NASLOV:

Peter Frantar, univ. dipl. geograf

Agencija Republike Slovenije za okolje

Vojkova cesta 1b, SI - 1000 Ljubljana, Slovenija

E-pošta: peter.frantar@rzs-hm.si

\section{Vsebina}

$1 \quad$ Uvod 41

2 Metoda izračuna elementov vodne bilance 41

2.1 Padavine 41

$\begin{array}{lll}2.2 & \text { Izhlapevanje } & 42\end{array}$

2.3 Odtoki 42

3 Bilanca Slovenije $\quad 42$

$\begin{array}{lll}3.1 & \text { Padavine } & 42\end{array}$

$\begin{array}{lll}3.2 & \text { Izhlapevanje } & 43\end{array}$

3.3 Odtok 43

4 Bilanca po glavnih porečjih $\quad 43$

4.1 Pomurje 44

4.2 Podravje 44

4.3 Posavje 44

4.4 Pokolpje 44

4.5 Posočje 44

4.6 Povodje jadranskih rek brez Posočja 45

5 Sklep 45

6 Literatura 45 


\section{Uvod}

Voda je na Zemlji prisotna $v$ treh fizikalnih stanjih: tekočem, plinastem in trdnem. Najdemo jo v vseh treh za človeka pomembnih okoljih: ozračju, morju in na kopnem. Voda lahko menja vsa okolja in agregatna stanja tako v prostoru kot času, in je dinamičen medij (WMO 1994; Jones 1997).

Vodna bilanca je razdelitev hidroloških procesov vodnega kroga na temelju sistemske analize, ki jih obravnavamo v določenem času in prostoru. Hidrološki sistem je celota elementov in njihovih medsebojnih odnosov ter značilnosti, ki so del velikega naravnega vodnega kroga na omejenem območju (Fürst 2006; Schöniger in ostali 2003; Neff in ostali 2004). V zasnovi enostaven sistem se pokaže ob izračunavanju za zelo zapletenega (Davie 2004). V članku bomo predstavili vodno bilanco oziroma elemente vodnega kroga po glavnih slovenskih porečjih.

\section{Metoda izračuna elementov vodne bilance}

Enačba za izračun vodne bilance temelji na teoriji vodnega kroga, kjer voda kroži med ozračjem in površjem Zemlje (Van Abs in ostali, 2000; Kolbezen in ostali 1998; WMO 1997; Schöniger in ostali 2003). Enačba vodne bilance je:

padavine $(\mathrm{P})=$ odtok $(\mathrm{Q})+$ izhlapevanje $(\mathrm{E})+$ sprememba vodnih zalog $(\mathrm{dS})$.

Vodna bilanca je odprt sistem (Hong in ostali 2006), v katerem lahko izračunamo dotoke in odtoke vode. Na Zemlji so poglavitni dotok padavine, poglavitni »odtok « pa je izhlapevanje (Ritter 2006), kar za Slovenijo ne drži. Pri izračunu vodne bilance za obdobje 1971-2000 nismo upoštevali sprememb vodnih zalog, saj smo predpostavili, da je ta člen bilance zaradi povprečenja v dolgoletnem obdobju zanemarljiv (Kolbezen in ostali 1998; Frantar in ostali 2005; Berezovskaya in ostali 2005), za letno bilanco pa je ta člen zelo pomemben (Koczot in ostali 2004; Sloto in ostali 2005; Neff in ostali 2005). Uporabili smo poenostavljeno enačbo vodne bilance, ki predpostavlja ravnovesje padavin $\mathrm{z}$ odtokom in evapotranspiracijo: padavine $(\mathrm{P})=\operatorname{odtok}(\mathrm{Q})+$ evapotranspiracija $(\mathrm{E})$.

Temeljni cilj našega dela je $\mathrm{z}$ uporabo rezultatov elementa vodne bilance odtoka v obdobju 1971-2000 in na podlagi 100-metrskega digitalnega rasterskega sloja podatkov potrditi ustreznost rezultatov izračunanih padavin in izhlapevanja ter $\mathrm{z}$ uporabo bilančne enačbe določiti povprečni letni odtok v Sloveniji. Posamezne elemente vodne bilance smo primerjali med seboj in jih popravili s pomočjo izračuna bilančne napake. $Z$ upoštevanjem rezultatov odtoka smo tako potrdili pravilnost izračunanih vrednosti padavin in izhlapevanja, s čimer je možna rastrska »bilančna« analiza v Sloveniji (slike 1, 3, 5).

\subsection{Padavine}

Padavine so definiciji atmosferska voda, ki po kondenzaciji in sublimaciji izhaja iz zraka in se zaradi težnosti premika proti tlem oziroma pade na tla (DIN 1996, citirano po Schöniger in ostali 2003). Padavine so najpomembnejši podnebni element hidrološkega sistema (Fürst 2006), saj so v krogu v naravnih pogojih edini dotok vodnega kroga (Van Abs et al. 2000). Oblika padavin je različna, v vodnobilančnih izračunih pa jih podajamo v ekvivalentih tekoče vode (Frantar in ostali 2006a; Fürst 2006).

Z meritvami padavin, ki potekajo na izbranih točkah na površini Zemlje, dobimo točkovne vrednosti. Izbranih je bilo 193 merilnih mest z vsaj 25 leti delovanja, osem meteoroloških postaj s krajšimi nizi v Sloveniji in 29 postaj iz Avstrije in Hrvaške. Te so pomembne zlasti na razgibanem mejnem reliefu, kjer je prostorska spremenljivost padavin zelo velika in zaradi hidroloških razvodnic (Frantar in ostali 2006d). Uporabno vrednost za bilanco smo dobili z ekstrapolacijo točkovnih vrednosti (Schöniger in ostali 2003) in s popravki meritev zaradi sistematične napake meritve (WMO 1994; Fürst 2006). Sistematične napake so v največji meri posledica napačnih meritev zaradi vetra, omočenosti ombrometra, izhlapevanja, izlitja ali transporta snega (WMO 1994). Točkovne podatke smo korigirali z dinamičnim korekcijskim modelom (Forland in ostali 1996; Nespor in ostali 1999), ki upošteva vrsto padavin ter intenziteto in hitrost vetra na dnevni ravni za vsak padavinski dogodek posebej (Frantar in ostali 2006a). Pridobljeni povprečni korekcijski faktorji za postaje so podobni, kot sta jih izračunala Pristov in Kolbezen (Kolbezen in ostali 1998) za povprečne padavine v obdobju med 1961 in 1990. 


\subsection{Izhlapevanje}

Ocena izhlapevanja ima za hidrološko bilanco izreden pomen. Izhlapevanje je fizikalni prehod vode s temperaturami pod rosiščem iz trdnega ali tekočega v plinasto stanje (Schöniger in ostali 2003). Evapotranspiracija je pojem, ki povezuje prehajanje vode $\mathrm{v}$ obliki vodne pare z zemeljske površine (evaporacijo) in iz rastlin (transpiracijo) (Allen 1998; WMO 1994; Schöniger in ostali 2003; Fürst 2006).

Referenčno evapotranspiracijo za obdobje 1971-2000 so izračunali po modificirani Hargreasovi metodi (Allen 1998) za 37 klimatoloških postaj na osnovi minimalne in maksimalne temperature zraka in lege postaje. Za slovensko klimatsko območje so Hargreasovo metodo utežili z linearnimi regresijskimi koeficienti glede na dnevne vrednosti evapotranspiracije po Penman-Montheithovi metodi (Allen 1998). Izračun velja za topli del leta in dobro namočena tla poraščena s travo, zato so vrednosti korigirane, da smo dobili dejansko evapotranspiracijo. Za korekcijo smo uporabili podatke o rabi tal iz baze Corine Land Cover (Frantar in ostali 2006d). Evapotranspiracija na površju je namreč zelo odvisna od vrste rabe tal (Jones 1997).

\subsection{Odtoki}

Odtoki so praviloma najzanesljiveje merjen člen vodne bilance. Na dobrih vodomernih postajah namreč vsa voda z vodozbirnega območja odteče skozi en sam profil, zato je zelo pomembna izbira ustreznih in kakovostnih vodomernih postaj. Med več kot 700 vodomernimi postajami smo izbrali take, ki delujejo ustrezno časovno obdobje in imajo primerno geografsko lego. Po večkratnem pregledu in usklajevanju členov vodne bilance smo določili tako imenovana hidrometrična zaledja, ki so osnovna enota za izdelavo vodne bilance. Hidrometrično zaledje je območje, ki je omejeno z razvodnicami, ter za katerega poznamo dotoke (na primer pretok na gorvodnih vodomernih postajah) in odtoke (Frantar 2003). Na podlagi rezultatov na območju posameznega hidrometričnega zaledja lahko primerjamo posamezne elemente vodnega kroga (Fürst 2006), s čimer lahko potrdimo pravilnost izračunanih vrednosti padavin in izhlapevanja z izmerjenim odtokom. Tako lahko izdelamo zemljevid povprečnega letnega odtoka $\mathrm{v}$ mm po tako imenovani klimatološki metodi z uporabo enačbe $\mathrm{Q}=\mathrm{P}-\mathrm{E}$ (Jones 1997).

\section{Bilanca Slovenije}

\subsection{Padavine}

V Sloveniji je v obdobju 1971-2000 padlo letno povprečno $1579 \mathrm{~mm}$ padavin. Prostorska porazdelitev padavin je močno povezana z reliefom (slika 1) (Schöniger in ostali 2003; WMO 1994). Zaradi orografskega učinka se količina padavin povečuje od morja proti notranjosti Slovenije in doseže višek na dinarsko-alpski pregradi. Največ padavin (nad $2600 \mathrm{~mm}$ ) pade na jugozahodni strani grebenov Julijskih Alp in Snežnika. Drugod v Julijskih Alpah, Karavankah in na robnih visokih dinarskih planotah pade povprečno letno med 2000 in 2600 mm padavin. Nekoliko manjši krajevni višek padavin je tudi v Kamniško-Savinjskih Alpah. Ob obali Jadranskega morja je letna količina padavin med 1100 in $1200 \mathrm{~mm}$. Proti severovzhodu, za dinarsko pregrado se z oddaljenostjo od morja in orografskih pregrad količina padavin hitro zmanjšuje. Večja količina padavin pade le še na Pohorju in Gorjancih (do $1800 \mathrm{~mm}$ ). V Ljubljanski kotlini količina padavin pada od severa proti jugu in je med $1300 \mathrm{~mm}$ na jugovzhodu kotline in $1800 \mathrm{~mm}$ na skrajnem severu kotline. V višjih predelih Posavskega hribovja pade letno do $1400 \mathrm{~mm}$ padavin, v nižjih predelih Posavskega hribovja, na Koroškem, Štajerskem do Maribora, na Dolenjskem in v Beli krajini pa pade med 1200 in $1300 \mathrm{~mm}$ padavin. Od Dravsko-Ptujskega polja, kjer dobijo letno med 1100 in $1200 \mathrm{~mm}$ padavin, se proti severovzhodu količina padavin še zmanjšuje. Na skrajnem severovzhodu države ne preseže $900 \mathrm{~mm}$.

Slika 1: Povprečna letna količina padavin v obdobju 1971-2000 v mm (Dolinar 2006).

Glej angleški del prispevka.

Slika 2: Velikost površja glede na količino padavin po razredih v Sloveniji.

Glej angleški del prispevka. 


\subsection{Izhlapevanje}

Regionalne razlike so med elementi vodnega kroga v Sloveniji najmanjše pri izhlapevanju (slika 4). Letno izhlapevanje v obdobju 1971-2000 je bilo med 458 in $879 \mathrm{~mm}$ oziroma povprečno $717 \mathrm{~mm}$. Izhlapevanje je predvsem odvisnost od nadmorske višine in vrste rabe tal (slika 3 ).

Največje izhlapevanje, nad $850 \mathrm{~mm}$, imajo posamezna gozdnata območja v Pomurju, določeni predeli Krško-Brežiške ravnine in del Bele Krajine. Na zahodu države so taka priobalna območja Koprskega gričevja, predeli Vipavskih brd ter zahodni kraški rob. Vmesni pasovi količine izhlapevanja so zelo razdrobljeni zaradi raznolike rabe tal. Majhno izhlapevanje z vrednostmi pod $600 \mathrm{~mm}$, je na manjših območjih gorskega in hribovitega sveta, večje pa na jugovzhodnem robu Pohorja, v Blejskem kotu, v visokogorju Julijcev, v območju Postojnsko-Pivške kotlinice, v Brkinih in na območju vzhodne Notranjske ter zahodne Dolenjske. Splošna značilnost je, da se izhlapevanje zmanjšuje od južne Slovenije proti severozahodu in severovzhodu države.

Slika 3: Povprečna letno izhlapevanje v obdobju 1971-2000 v mm (Kurnik 2006).

Glej angleški del prispevka.

Slika 4: Površina glede na količino izhlapevanja po razredih v Sloveniji.

Glej angleški del prispevka.

\subsection{Odtok}

Naravnogeografska pestrost Slovenije se kaže v veliki variabilnosti odtoka. Odtok pada od alpsko-dinarskega pasu med Julijci in Snežnikom proti jugozahodu in severovzhodu. Povprečni letni odtok v obdobju 1971-2000 je bil $862 \mathrm{~mm}$. Glavna geografska značilnost razporeditve odtoka je, da količina pada od severozahoda proti jugu in vzhodu države. Razporeditev je odvisna od reliefa - višji predeli imajo praviloma večji odtok, medtem ko je ta v okoliškem nižje ležečem svetu precej manjši.

Letno v povprečju največ vode (več kot $2000 \mathrm{~mm}$ ) odteče iz osrednjega dela Julijcev, najvišjih predelov Trnovskega gozda in Snežnika. To so najbolj namočeni predeli Slovenije, kjer je hiter podzemski in površinski odtok padavin. Poleg teh imajo več kot $2000 \mathrm{~mm}$ odtoka letno še najvišji predeli Karavank in Kamniško-Savinjskih Alp. Med 1500 in 2000 mm odtoka letno imajo predalpska hribovja Julijcev ter zahodne dinarske planote od Banjšic do Snežnika. Območja z odtokom med 1200 in 1500 mm so v zahodni Sloveniji: predgorja Julijskih Alp, Karavank in Kamniško-Savinjskih Alp, Škofjeloško in Idrijsko hribovje, severni del Goriških Brd, obrobje zahodnih dinarskih planot, Javorniki in območje Goteniške gore.

Pas med 900 in 1200 mm odtoka letno obsega območja od južnih Brd do Slavnika, območja od Doline do vzhodnih Kamniško-Savinjskih Alp in prek vzhodnih delov Škofjeloškega hribovja vse do Kočevske Male gore ter Roga in Pohorja.

Med 600 in 900 mm odtoka imajo pokrajine na jugozahodu: Vipavska brda, Kras, del Brkinov in vzhodni del Koprskega primorja. Največje območje s takim odtokom je v osrednji Sloveniji, od Suhe krajine na jugu prek Ljubljanske kotline vse do Pohorja in Kozjaka.

Nizki odtoki z vrednostmi med 300 in $600 \mathrm{~mm}$ prevladujejo v Koprskem primorju in v vzhodni Sloveniji od Bele krajine do Slovenskih goric. Vrednosti odtoka pod $300 \mathrm{~mm}$ so v Pomurju, kjer ponekod izhlapevanje presega količino padavin.

Slika 5: Povprečni letni odtok v obdobju 1971-2000 v mm izdelana na podlagi bilančnega računa P - ETP.

Glej angleški del prispevka.

Slika 6: Površina glede na količino odtoka po razredih v Sloveniji.

Glej angleški del prispevka.

\section{Bilanca po glavnih porečjih}

Rezultati vodnobilančnih elementov kažejo na veliko pestrost klimatogeografskih in hidrogeografskih razmer $\mathrm{v}$ slovenskih porečjih. $\mathrm{V}$ tem poglavju smo v obravnavanih glavnih porečjih opisali padavine, izhlapevanje in odtoke.

Slika 7: Elementi vodne bilance po porečjih v mm.

Glej angleški del prispevka. 


\subsection{Pomurje}

Pomurje je regija z najmanjšimi količinami vode v Sloveniji. V povprečju imamo tu $897 \mathrm{~mm}$ padavin, izhlapi $693 \mathrm{~mm}$ in odteče $204 \mathrm{~mm}$ vode letno. Na levem bregu Mure je padavin povsod manj kot $900 \mathrm{~mm}$, na skrajnem vzhodnem delu celo manj kot $850 \mathrm{~mm}$. Največ jih imajo Slovenske gorice, kjer je ponekod tudi več kot $1000 \mathrm{~mm}$ padavin letno. Povprečno izhlapi $693 \mathrm{~mm}$, količina je enaka v vsem Pomurju. Izhlapevanje je odvisno od rabe tal - največ vode izhlapi iz gozdnatih območij. Zaradi visokega izhlapevanja in majhne količine padavin so tu najnižji odtoki v državi. Okrog $300 \mathrm{~mm}$ vode odteče z desnega brega Mure, od tam pa količina pada proti vzhodu. Marsikje v Pomurju je izhlapevanje celo večje kot razlika padavin in odtoka, kar je razumliivo, saj tu prevladujejo plitvi vodonosniki.

\subsection{Podravje}

Slovenski del Podravja zajema bolj raznolike pokrajine kot Pomurje. Območje lahko razdelimo na Slovenske gorice, nižinski južni del desnega brega Drave z njeno dolino ter hribovit severni del s Pohorjem in zahodnimi Karavankami.

Tu pade povprečju letno $1244 \mathrm{~mm}$ padavin, izhlapi $697 \mathrm{~mm}$ in odteče $547 \mathrm{~mm}$ vode. Povsod v Podravju imamo nad $1000 \mathrm{~mm}$ padavin. Najmanj jih je v Slovenskih goricah, kjer jih je v južnem delu okrog $1000 \mathrm{~mm}$, v severnem pa okoli $1100 \mathrm{~mm}$. Območje nižinskega dela Dravsko-Ptujskega polja, Haloz in obronkov Pohorja ima več kot $1200 \mathrm{~mm}$ padavin. Količina padavin odtod rasteta proti višjim delom Pohorja in zahodnih Karavank, kjer jih je nad 1600 mm. Izhlapevanje je najmanjše na območju Slovenskih goric in Dravskega polja ter v najvišjih delih predelih porečja Drave - na Pohorju in v povirju Meže, kjer izhlapi manj kot $650 \mathrm{~mm}$ letno. Drugod izhlapi več kot $700 \mathrm{~mm}$, največ ponekod v Halozah in sicer več kot $800 \mathrm{~mm}$. Odtoki kažejo podobno sliko - najmanjši so na vzhodnem delu (okrog $300 \mathrm{~mm}$ letno), največji pa v višjih predelih Pohorja in Karavank, kjer presežejo 1100 mm letno.

\subsection{Posavje}

V Posavju je v obdobju 1971-2000 na leto povprečno padlo $1594 \mathrm{~mm}$ padavin, izhlapelo $716 \mathrm{~mm}$ in odteklo $878 \mathrm{~mm}$ vode. Padavinska slika Posavja je zelo raznolika. V najbolj namočenih predelih Julijcev, v povirju Save Bohinjke pade več kot $3000 \mathrm{~mm}$ padavin. Količina padavin se od tod naglo zmanjšuje proti severu in vzhodu. Več kot $2500 \mathrm{~mm}$ padavin je tako le še v dolini Vrat, na Pokljuki in delno na Jelovici. Večina planot Julijskih Alp, Karavanke in Kamniško-Savinjske Alpe ter deli predalpskega hribovja in Javornikov imajo med 2000 in $2500 \mathrm{~mm}$ padavin. Količina odtod pada proti vzhodu, tako da prejme osrednji del Posavja med 1400 in $1800 \mathrm{~mm}$ padavin, velik vzhodni del pa manj kot $1400 \mathrm{~mm}$. Najmanj padavin v Posavju je v Posotelju - pod $1200 \mathrm{~mm}$ na leto. Izhlapevanje je v Posavju najmanjše v visokogorskem Alpskem svetu (manj kot $550 \mathrm{~mm}$ letno) in ob Sotli (okoli $650 \mathrm{~mm}$ letno). Iz Posavja povečini izhlapeva med 650 in 850 mm letno, manj na severu in več na jugu. Na manjših območjih izhlapi več kot 850 mm (Krško-Brežiško polje). Odtok je v Posavju razporejen podobno kot padavine. Največ odteče iz alpskih (več kot $2500 \mathrm{~mm}$ ) in predalpskih območij, odtod pa količina pada proti vzhodu, kjer je odtoka za 300-600 mm.

\subsection{Pokolpje}

V slovenskem delu Pokolpja v povprečju pade $1534 \mathrm{~mm}$ padavin, izhlapi $757 \mathrm{~mm}$, odteče pa $777 \mathrm{~mm}$ vode letno. Na zahodu, to je na robu Snežnika in na Kočevskem je več kot $2000 \mathrm{~mm}$ letno. Osrednji del ima okrog $1700 \mathrm{~mm}$ padavin, porečje Lahinje pa okrog $1300 \mathrm{~mm}$. Izhlapevanje je zelo visoko, od 650 do več kot $850 \mathrm{~mm}$ letno. Odtok je največji v zgornjem delu porečja Kolpe, več kot $1600 \mathrm{~mm}$, od tod pa se proti vzhodu zmanjšuje. Najmanjši je v osrednji Beli krajini, kjer odteče zgolj okoli $400 \mathrm{~mm}$ vode letno.

\subsection{Posočje}

Posočje je naše najbolj namočeno porečje. V povprečju pade tu $2386 \mathrm{~mm}$ padavin, izhlapi v $726 \mathrm{~mm}$ in odteče $1660 \mathrm{~mm}$ vode letno. Količina padavin pada od severa proti jugu porečja. Njegovi najvišji deli ima- 
jo več kot $3000 \mathrm{~mm}$ padavin letno, visokogorski predeli Julijcev celo več kot $3500 \mathrm{~mm}$. V alpskih dolinah je padavin že med 2300 in $2700 \mathrm{~mm}$, saj se del padavin zaustavi že na južnejših visokogorskih pregradah. Jugozahodni rob visokih dinarskih planot od Kambreškega, Banjšic do Trnovskega gozda prejme okrog $2300 \mathrm{~mm}$. V predalpskem hribovju ter na Nanosu je padavin že manj, to je med 2000 in $2300 \mathrm{~mm}$ na leto. Pod $2000 \mathrm{~mm}$ padavin je v Goriških brdih in v zgornji Vipavski dolini. Najmanj padavin imajo spodnja Vipavska dolina in Vipavska brda, in sicer okoli $1500 \mathrm{~mm}$ letno. Izhlapevanje je največje na jugu Posočja, kjer na določenih območjih izhlapi več kot $850 \mathrm{~mm}$ letno. Izhlapevanje pada proti severu skladno $\mathrm{z}$ nadmorsko višino in je $\mathrm{v}$ visokogorju Julijskih Alp le še okrog $550 \mathrm{~mm}$ letno. Velike razlike so v odtoku. Na Kaninskem pogorju odteče več kot $3000 \mathrm{~mm}$ vode, v večini posoških Julijskih Alp pa je odtok večji od $2000 \mathrm{~mm}$ (z izjemo dolin). Več kot $1500 \mathrm{~mm}$ odteče z dinarskih pregrad in iz osrednjega dela Posočja. V dolini Idrijce letno odteče približno $1100 \mathrm{~mm}$ vode, v Vipavskih brdih pa le še $650 \mathrm{~mm}$ letno.

\subsection{Povodje jadranskih rek brez Posočja}

Najmanjši hidrogeografski del Slovenije so porečja Notranjska Reka in rek, ki se izlivajo neposredno v Jadransko morje. Povprečno pade letno $1619 \mathrm{~mm}$ padavin, izhlapi $748 \mathrm{~mm}$ in odteče pa $871 \mathrm{~mm}$ vode. Največ padavin ima okolica Snežnika, in sicer več kot $2500 \mathrm{~mm}$. Od tam količina pada proti zahodu, tako da ima obala Jadranskega morja približno $1100 \mathrm{~mm}$ padavin, zahodni Kras pa okrog $1500 \mathrm{~mm}$. Izhlapevanje je največje ponekod v Koprskih brdih in na jugozahodu Krasa (več kot $850 \mathrm{~mm}$ ). Proti severu in vzhodu se izhlapevanje zmanjšuje, in je na Snežniku manjše od $700 \mathrm{~mm}$ letno. Odtoki so največji v okolici Snežni$\mathrm{ka}(\mathrm{nad} 2000 \mathrm{~mm}$ ) in se od tam proti zahodu zmanjšujejo. V Koprskem primorju so le med 200 in $400 \mathrm{~mm}$ letno.

\section{Sklep}

Slovenija je v svetovnem merilu nadpovprečno namočena dežela. Na celinah pade povprečno $750 \mathrm{~mm}$ padavin, izhlapi $480 \mathrm{~mm}$ in odteče $270 \mathrm{~mm}$ (Global Water Balance 2006; Fürst 2006). V Sloveniji je v obdobju 1971-2000 padlo povprečno letno $1579 \mathrm{~mm}$ padavin, izhlapelo je $717 \mathrm{~mm}$, skupni izmerjeni odtok pa je bil 862 mm. Da je Slovenija še vedno dobro namočena kaže odtočni količnik, ki je v Sloveniji (55\%) večji kot je povprečni odtočni količnik na Zemlji, ki je 36 \% (Schöniger in sotali 2003, citirano po Baumgartner in ostali 1996).

Preglednica 1: Vodna bilanca Slovenije v obdobjih 1961-1990 in 1971-2000 v mm (Kolbezen et al. 1998).

\begin{tabular}{lcc}
\hline & $1961-1990$ & $1971-2000$ \\
\hline padavine & 1567 & 1579 \\
izhlapevanje & 650 & 717 \\
odtok - izračunan $(Q=P-E)$ & 917 & 862 \\
odtočni količnik & $58,5 \%$ & $54,5 \%$ \\
\hline
\end{tabular}

Primerjava naših izračunov z vodo bilanco Slovenije za obdobje 1961-1990 (Kolbezen in ostali 1998) kaže, da so bile obdobju 1971-2000 količine padavin skoraj enake, povečalo se izhlapevanje in zmanjšal odtok. Izhlapevanje je večje za enajst, odtok pa je manjši za šest odstotkov.

Podnebne spremembe se odražajo tudi v količini vode. Večina tako temperaturnih kot tudi hidrološko-nevihtnih indikatorjev podnebnih sprememb (Houghton in ostali 2001) kaže na spremembe v Sloveniji zlasti po letu 1990 (Nadbath 1999; Gabrovec 1998; Frantar 2004). Smiselno bi bilo izdelati vodno bilanco za daljše obdobje, in sicer po posameznih desetletjih in letih. V vsakem pogledu postaja voda vse dragocenejša naravna dobrina.

\section{Literatura}

Glej angleški del prispevka. 